\title{
Herman Tieken
}

\section{The Dissemination of Aśoka's Rock and Pillar Edicts*}

\section{INTROduction}

The corpus of inscriptions attributed to the Maurya emperor Aśoka ${ }^{1}$ includes two sets of inscriptions which each appear as a series. The Rock Edict (RE) series consists of fourteen consecutive proclamations carved on large boulders at nine widely scattered sites (including the fragments of Sōpārā and Sannathi); the Pillar Edict (PE) series consists of seven proclamations found on free-standing pillars at six different places. ${ }^{2}$ With one exception (in Erragudi), ${ }^{3}$ the edicts occur everywhere in exactly the same order. This would suggest that the texts of both the Rock and Pillar Edicts were received at those places as existing and complete series. However, as far as I know this conclusion has never been explicitly drawn. Instead, all options regarding this matter seem to have been kept open. Thus, Norman, for instance, writes: "the fact that at all sites ... PEs 1-6 were inscribed while the pillars were lying horizontally on the ground implies either that all six edicts were received at the same time, or that the scribes were informed that more edicts were on their way and the pillars should not be raised until they

* I have profited greatly from discussions on Aśoka and the Aśoka inscriptions with Jos Gommans, Jan Heesterman, Shereen Ratnagar, Tillmann Vetter and Willem Vogelsang. I would also like to thank Anne MacDonald, Karin Preisendanz and especially Chlodwig $\mathrm{H}$. Werba for their interest in the topic of the article and their remarks and suggestions.

1 For the so-called Rock Edicts (RE), the references are to the texts as reconstructed by Schneider 1978; for the two Separate (Rock) Edicts (SE) of Dhauli (Dh.) and Jaugada (J.), I quote from Alsdorf 1962. Note that Alsdorf's SE I is Hultzsch's II (Hultzsch 1925). I have retained the alphabetical labels of the sentences introduced by Hultzsch; for the Minor Rock Edicts (MRE), I refer to Andersen 1990; for all the remaining edicts, which include the Pillar Edicts (PE), I refer to Hultzsch 1925.

2 For maps showing the distribution of Aśoka's edicts, see Allchin-Norman 1985. Note that the fragments of the texts of the Rock Edicts at Sōpārā (Hultzsch 1925: xv) and Sannathi (Ramesh 1990) are not found on rocks but on stone slabs.

3 The confusion of the order in Erragudi seems to have been caused by the fact that the edicts are distributed over several smaller, dispersed boulders. 
had arrived, or that each edict arrived before the carving of the preceding one had been finished and the pillar had been erected" (Norman 1987: 137).

Norman's scenario applies in the first place to the Pillar Edicts, which were all (except for the seventh) issued within the span of one year, namely in the twenty-sixth year of the emperor's reign. However, in the case of the Rock Edicts the situation is much more complicated. Of these, only the fourth has been formally dated, namely in the emperor's twelfth year. The fifth edict - and something similar is seen in REs III, VIII, and $\mathrm{XIII}^{4}$ - refers to the institution of a particular kind of officer by the emperor in his thirteenth year. All we can say about the date of this edict is that it was issued some time after the thirteenth year.

If the edicts, which for all we know belonged to different years, were indeed disseminated gradually and individually, complications arise when we turn to the stemmatical relationships existing between the different versions of the Rock Edict series. The edicts at the various sites, which occasionally show considerable textual variation, were divided by Schneider (1973 and 1978: 9-19) into two recensions. The versions of Girnār in the west and Dhauli and Jaugada in the east have many new features in common in practically all edicts of the series. These three versions appear to constitute a separate recension distinct from the one transmitted in the four other versions from the northwest (Mānsehrā and Shāhbāzgaṛhī), the north (Kālsī) and the south (Erragudi). However, it is not easy to explain how the local authorities of Girnār, after having received the text of Edict I from the source which also fathered the Dhauli and Jaugada versions, years later received the text of Edict XIV from this very same source. In fact, the easiest way to explain the close stemmatical relationship between Girnār, on the one hand, and Dhauli and Jaugada, on the other, is to assume that the edicts were disseminated as a set.

Scholars appear to have been reluctant to draw this conclusion. One of the reasons for this is probably the absence of convincing internal evidence. However, as I will try to show, we are not dealing with two sets of inscriptions which originated more or less accidentally and over the course of time. Instead, we appear to be dealing with two carefully

4 In RE III the emperor is "quoting" an edict issued by him in his twelfth year, in RE VIII he mentions his visit in his tenth year to the place where the Buddha received enlightment, and in RE XIII he refers to the conquest of Kalinga in his eighth year, but the edict itself is issued "now, (long) after that". 
selected compilations of edicts, one of which was to be engraved along the outer borders of the empire, and the other in the centre of it. The content of each series appears to have been specifically adapted to its intended audience.

It will be clear that it makes a considerable difference for the reconstruction of the history and function of the inscriptions if they were simultaneously disseminated as a series and not gradually and individually. For instance, while RE IV was issued in the twelfth year, on the basis of $\mathrm{RE} \mathrm{V}$ it is clear that the series as a whole can only have been compiled some time after the thirteenth year. This means that against the (often tacit) assumption that the edicts were drawn up for the specific purpose of serving as texts for inscriptions, we will have to make a distinction between the edicts proper and the inscriptions, the latter representing a secondary use of existing documents. Both the edicts and the inscriptions will each have had their own specific functions, which have to be determined all over again.

Another problem to be reconsidered is the relationship between the Rock Edicts, on the one hand, and the Pillar Edicts, on the other. The Pillar Edicts, or at least the first six of them, are all dated to the twenty-sixth regnal year. At first sight it is as if the emperor, after having dispatched Rock Edicts to the extreme corners of the realm during the first part of his reign, in the second became more interested in the core area of the realm and caused inscribed pillars to be erected there. However, on closer inspection the time gap between the "earlier" Rock Edict inscriptions and the "later" Pillar Edicts may have been much less than assumed so far, if there was one at all. For all we know the Rock Edict series might have been issued as late as the twenty-sixth year. In any case, the thirteenth year of $\mathrm{RE} V$ is no more than a date post quem. Given this, it is important to note that, as I will try to show, the two series of edicts are virtually complementary, each having been directed at an "audience" of its own. This would suggest that the dissemination of the Rock Edicts to the outer districts and that of the Pillar Edicts to the districts lying in the interior were part of one and the same centralized undertaking.

Finally, then arises the question of whether the compilation of the texts of the inscriptions and their dissemination indeed took place during the lifetime of the emperor in whose name the edicts were originally issued. As I will argue, we should reckon with the possibility that the inscriptions were not, in which case we would be dealing with monuments 
dedicated to a past ruler who had already acquired legendary status. As such the inscriptions provide evidence corroborating the Buddhist legends about Aśoka, whose name is indeed found, albeit as a later insertion, in some of the inscriptions.

\section{The Rock Edict Series as a Compilation}

Schneider (1978: 152-176) divides the series of fourteen Rock Edicts into three blocks: I-IV, V-XIII, and XIV. He distinguishes between an original series, formed by I-IV, and material which has been added more or less randomly later (V-XIII and XIV). As far as section V-XIII is concerned, Schneider was not able to detect even a trace of a system which could account for the sequence as a whole. ${ }^{5}$ All he could point to are occasional thematic connections between pairs of immediately following edicts, with the criteria changing from case to case. The situation in I-IV is no better, as this block was subdivided by Schneider into two pairs of edicts, namely I-II and III-IV.

Thus Schneider was unable to find a principle which could account for the selection of the edicts in the series as a whole. According to Schneider, we are ultimately dealing with a random collection of edicts, which had grown over a certain period of time. In this connection the following two points discussed by Schneider may be mentioned. Regarding the Edicts III and IV he concludes that this pair, despite their close formal connection, can hardly have been written (or engraved) at the same time. ${ }^{6}$ Likewise, in connection with the sequence of Edicts IV and $V$ Schneider notes that the order of the edicts is chronological, reflecting a development in the emperor's political thought. ${ }^{7}$ The main point of discussion for Schneider is the time or the number of years involved in this development (op.cit., p. 160-163).

5 "Es sieht so aus, als seien von VII an die Edikte nur noch lose, fast möchte man sagen: nach Bedarf oder Gutdünken, angehängt worden, ohne daß sich Aśoka über ihre logische Abfolge viel Gedanken gemacht hätte" (Schneider 1978: 164).

6 "Allenfalls könnte man ... den starken Verdacht äußern, daß III und IV trotz ihrer engen formalen Zusammengehörigkeit, kaum in einem Zuge geschrieben (und eingemeißelt) wurden" (Schneider 1978: 160). On the same page, while discussing the following block of edicts, Schneider wishes to leave open "ob dann das Ganze auch in einem Zuge oder nur stückweise diktiert, bzw. geschrieben wurde".

7 "Wachsende Schwierigkeiten ... werden es am ehesten gewesen sein, die ihn zu den in V sich widerspiegelnden härteren Maßnahmen - und in diesem Zusammenhang auch zur Fortsetzung der, ursprünglich mit IV abgeschlossenen, EdiktReihe - veranlaßt haben" (Schneider 1978: 163). 
One argument for the Rock Edict series not being a random collection but rather a careful compilation is furnished by the fourteenth and final edict, which seems to serve as a veritable captatio benevolentiae to the preceding text:

[A] iyam dhammalipi devānampiyena piyadasinā lājinā likhāpitāa: athi yeva samkhitena, athi majhimena, athi vithațena.

[B] no hi savatā save ghațte.

[C] mahālake hi vijite bahu ca likhite likhāpayisāmi ceva nikāyaṃ.

[D] athi cu heta puna puna lapite tasa tasa ațasa mādhuliyāye ena: jane tathā patipajeyā.

[E] se siyā ata kichi asamati likhite desam vā samkhāya kālanam vāa alocayitu lipikalāpalādhena vā $t i$.

Schneider translates the edict as follows (1978: 119):

[A] Diese Schrift über den Dhaṃma ist auf Veranlassung des Königs D.P. geschrieben worden: Sie existiert schon, sei es in mehr oder weniger abgekürzter, sei es in ausführlicher (Form).

[B] Denn nicht überall paßt alles.

[C] Denn weit ist mein Reich, und viel ist geschrieben worden; und ich werde auch in Zukunft (?) noch weiter schreiben lassen.

[D] Es ist aber schon in dieser Hinsicht immer wieder gesagt worden, wegen der Unwiderstehlichkeit [wörtlich: "Süßigkeit"] der verschiedenen Themen (und) damit die Leute sich entsprechend verhalten. ${ }^{8}$

[E] Es mag sein, daß hier oder dort irgendetwas unterschiedlich geschrieben wurde, entweder, weil die Region [= der betreffende Teil des Reiches] einzukalkulieren war oder weil ich an einem Anlaß [scil. das Betreffende da zu schreiben] keinen Gefallen gefunden hatte, oder infolge einer Nachlässigkeit des Schreibers.

Bloch (1950: 133, n. 1) rightly characterized this edict as a "post-face". Indeed, contrary to the preceding edicts, it does not provide instruction, and instead apologizes for elements in the texts which may have annoyed (repetition, writing mistakes) or confused (different versions) the reader.

The preceding thirteen edicts may be roughly divided into two groups, namely I-III and IV-XIII. IV-XIII may be divided again into two sec-

8 This sentence will be discussed by me in more detail in a forthcoming article entitled "The Aśoka Inscriptions and the Original Milieu of the Kāvya Poetic Tradition". 
tions, namely IV-VIII and IX-XIII. This division of IV-XIII is based partly on formal aspects. To begin with section IV-VIII, all these edicts (with the exception of VII) share a similar pattern and terminology. First they mention the past (atikamtam amtalam in IV A, V H, VI B, VIII A), in which, for instance, many living beings were killed. Next, the focus switches to the emperor's own time, in which the killing of living beings does not take place any longer. Some of the edicts (IV and V) go even one step further and mention measures undertaken by the emperor which should ensure that in the future the situation will not relapse, but instead will improve.

With IX the pattern and terminology change. In section IX-XIII the emperor introduces a distinction between ordinary liberality or ordinary ceremonies, on the one hand, and dharma-liberality and dharmaceremonies, on the other. Only the latter type of undertakings he deems (ma[m]nati) fruitful (mahāphala or mahathāvaha) because they are done with the life in the hereafter in mind (palata, pālatika). A variant of the expression (ma[m]nati) mahāphala/mahathāvaha found in IX, X, XII and XIII is the phrase "There is no liberality (so beneficial) as dharmaliberality" (nathi hedise dāne ādise dhammadāne), found in XI B and IX $p^{1}$.

It should immediately be added that the division between these two groups is not completely watertight. That is to say, a reference to happiness in heaven is also found in VI (L). On the other hand, no reference to the past (atikamtam amtalam) is found in the second group. Furthermore, because of the absence of the phrase atikamtam amtalam in RE VII, its positioning in the atikamtam amtalam group is unclear. Unfortunately, other possible factors which might account for the present position of this extremely brief edict are not clear.

If group IV-XIII is indeed mainly concerned with formal aspects, the edicts providing samples of types of edicts, this is only part of the picture. In addition it is possible to detect in section IX-XIII a kind of logical order, with the edicts as it were working towards a particular point. Thus, after the enumeration of all kinds of activities (e.g. ceremonies, the acquisition of fame, and liberality), which are contrasted to their dharma-inspired counterparts, in RE XIII three different types of conquest are mentioned. The third type of conquest is the so-called dharma-conquest (dhammavijaya), which the emperor considers the most fruitful of the three because it brings happiness in this life as well as in the hereafter (see XIII P: iyam cu mokhyamute vijaye devānam- 
piyasa e dhammavijaye, and X-Y: tamm eva ca vijayam mamnaṃtu e dhammavijaye. se hi hidalokikapālalolike). This type of conquest is characterized by the absence of any element of force or violence and consists basically of advertizing one's ideas and trying to convert people to them. The dharma-conquest is applied in particular to the people living at and beyond the outer limits of the empire - precisely where the Rock Edicts are found!

This outcome seems to be foreshadowed in the beginning of the series. Thus in I-III we can see how the scene shifts quite explicitly from the emperor's palace to the realm as a whole and its neighbours and to the neighbours of its neighbours. The emperor is thus indirectly presented as attempting to introduce ideas which he practiced at home into his vast realm and even beyond.

After an introduction (iyam dhammalipi devānampiyena piyadasinā lājinz likhāpitā A) RE I opens with the word hida "here". Opinions have been divided as to whether this hida refers to the capital, the realm, or the site where the inscription is found (see Schneider 1978: 120-121). In an attempt to reach a decision in this matter, we might have a look at the measures enumerated in the edict. First (B) the emperor mentions that "here" he has abolished animal sacrifices. After this (C-E) he says to have limited the number of samājas to the necessary minimum. As in the case of the abolishment of animal sacrifices, the motive behind this measure was most likely to minimize the killing of animals, for festive gatherings used to involve large dinner and drinking parties. So far we seem to have to do with public or official occasions. Next (F), the emperor seems to switch to more private matters and describes how he has managed to reduce the number of animals killed in his own palace kitchen for the sake of his daily meals (sūpathāye). In my opinion, the emperor does not switch in this edict from the great achievement of having abolished the killing of animals in his entire realm to reducing the quantity of meat in his own private menu. Instead, the enumeration proceeds from killing no animals (abolishment of sacrifices), to killing animals occasionally (in the case of necessary gatherings ${ }^{9}$ ), to killing animals daily (anudivasam $[\mathrm{F}]$ ), but in this case only a few (in

9 In this connection I would like to refer to, for instance, the akșapatala meetings, described in Arthaśāstra 2.7. During this meeting the mahāmātras reported their activities during the last year (or season or month). 
the palace kitchen). ${ }^{10}$ The implication of the enumeration is that like the third the first two measures would concern in the first place occasions at which the emperor is present in person or in the organization of which he is personally involved.

If hida in RE I indeed refers to the emperor's capital or home base, in II the scene shifts radically. Edict II opens with the words savatā vijitasi "everywhere in the realm". The horizon is extended even further by a list, which follows immediately, of the people neighbouring on the realm, namely the Greek kings in the northwest and, e.g., the Cholas in the south. As regards the Greek kings in the northwest the edict also refers to the people living beyond these Greek kings. ${ }^{11}$ After this are mentioned, among other things, the facilities which the emperor had provided everywhere along the roads for men and beasts.

After some introductory formulae RE III, like RE II, opens with the words savata vijitasi $(\mathrm{C})$. This is followed by the description of a measure introduced by the emperor in the twelfth year of his reign, namely inspection tours made once every five years by the yutas, lājuk kas and pādesikas. During these tours the said officials are to see to (1) "this

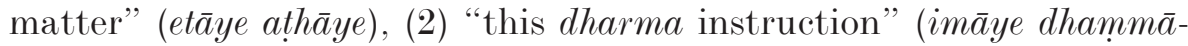
nusathiye), and (3) "(any) other business" (amnāye pi kammane [C]). It is tempting to take the first measure (1) as referring to the maintenance of the facilities mentioned in RE II. If so, it could, as Schneider would have it (1978: 122), of course also include the promotion of the abolition of sacrifices mentioned in RE I. In any case, the edict itself does not seem to contain a specification or example of what is meant with etāye athaye, unless it refers to the institution of the inspection tours itself. In this respect the case of the two following measures is different. Thus, D seems to supply an example of a dharma instruction (2): sādhu $m \bar{a}$ -

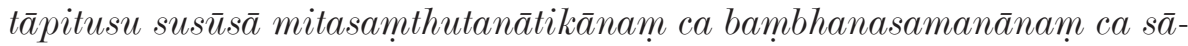
dhu dāne pānānam anālambhe sādhu. The next phrase, apaviyatā apabham too much", concerns financial matters, and seems in its turn to provide an example of the type of business involved under the heading amnāye pi kammane (3).

10 As noted by Zimmermann (1987: 182), "The meat diet was a feature of royalty and served not only as an observable fact of life but also as a representative model of life".

11 A more complete description of the realm is furnished in RE XIII, which adds Orissa (C) as well as, among others, the Bhojas from the west (Q). 
From PE IV ${ }^{12}$ it appears that the yutas and lajūkas mentioned here are independently operating local rulers or administrators. PE IV mentions their atapatiye, or autonomy ( $\mathrm{D}$ and $J$ ). The very name or title pādesika suggests that we are dealing with a local administrator as well. The position in the administration of the palis $\bar{a}$ mentioned in $\mathrm{E}$ (palis $\bar{a} p i$ ca gananasi yutāni anapayisa[m] ti hetute ca viyamjanate $c a)$ is unfortunately less clear. It all depends on whether palisa is singular (the emperor's parisad) ${ }^{13}$ or plural (the yutas' own parisads) as well as on the meaning of the verb anapayisa(m)ti ("order" or "inform"; in the latter case we might translate: "the [local] parisads inform the yutas [and $l \bar{a} j \bar{u} k a \mathrm{~s}$ and $p \bar{a} d e s i k a \mathrm{~s}$ ] about the calculations by [supplying] reasons and specifications").

Whatever is exactly the case here, RE III does contain a silent admission that the emperor cannot personally check upon the way his instructions are being implemented by the local authorities. Given the extent of the realm, the emperor simply has to leave matters to the local authorities. Completely in accordance with this, the ideas and measures mentioned in the edicts which follow (IV-XIII) seem to lie in the sphere of ethics rather than in that of practical government. Furthermore, the edicts IV-XIII seem to have served mainly as examples of types of edicts such as were issued by the emperor, which further reduces their practical use. In any case, at the moment of the compilation of the series the measures mentioned in them appear to have been secondary to aspect of format and vocabulary. In addition, the Rock Edicts are not systematically dated, as a result of which they lack a temporal context, and the measures announced in them are removed even further from the daily practice of government. All these peculiarities become all the more clear if we compare the Rock Edicts with the Pillar Edicts, which will be discussed next and which will appear to breathe a completely different spirit.

In the above I have tried to show that the Rock Edict series is not the random collection it has often been taken to be. For one thing, it appears to have been arranged according to at least some plan, with an

12 See below, p. 16. PE IV will be discussed by me in more detail in a forthcoming article entitled "The Interrogative Pronouns kam, kāni and kiṃti in the Aśoka Edicts".

13 Note, however, that according to PE IV G-H the contacts between the emperor and the local administrators such as the yutas were not maintained by the emperor's parisad (palis $\bar{a}$ ) but by his pulisas or "men". 
introduction (I-III) and a conclusion (XIV). The group in the middle may be divided into two subgroups on the basis of formal criteria. It is also possible to detect some logical order, in the sense that the scene goes from the emperor's own home base in I to the policy to be adopted towards the people living at and beyond the outer limits of the empire. Interestingly, it is at sites facing these people that the Rock Edict inscriptions are found.

\section{The contents of the Pillar Edicts}

One of the more obvious differences between the Rock and Pillar Edicts concerns the dates. Thus, while some of the Rock Edicts, since the Edicts presumably cover the entire period of the emperor's reign, would no longer have been topical at the time of their engraving, six of the seven Pillar Edicts belong to one and the same, the twenty-sixth year of his reign. ${ }^{14}$ Thus the Pillar Edicts are provided with a context. It is as if in the inscriptions we are dealing with real edicts and as if the measures announced in them are topical, requiring the immediate attention of the authorities. Interestingly, at the same time, the importance of edicts in government is downplayed in favour of a more direct contact of the emperor with the local authorities. In what follows I will try to show that, like the Rock Edicts, the Pillar Edicts, or at least the first six of them, do not form a random collection but that their arrangement betrays some definite design.

In RE XI the emperor as a true mìmāmsaka distinguishes between ordinary ceremonies leading to happiness in this life and so-called dharma-ceremonies, which lead to happiness both in this life and in the hereafter. In PE $\mathrm{I}^{15}$ the emperor returns to this combination by noting that this happiness is difficult to realize without the utmost (aga) lust (kāma) for dharma, the utmost prudence, the utmost obedience, the utmost fear of sin and the utmost energy. ${ }^{16}$ The emperor continues by noting that as a result of his own instruction (presumably through

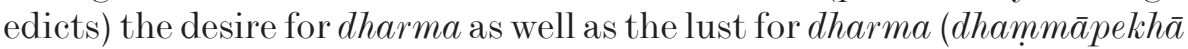
dhammak $\bar{a} m a t \bar{a} c \bar{a})$ has increased and will continue to increase (D). His

14 I shall return to the status of PE VII in the Pillar Edict series below, p. $27 \mathrm{f}$.

15 Unless otherwise stated, references to, and quotation from, the Pillar Edicts are based on the Delhi-Tōprā version.

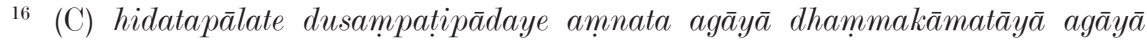

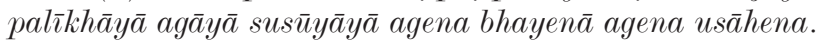


officials are involved in the implementation of this dharma politics as well. Here the emperor distinguishes between pulisas (E), i.e., officials directly answerable to him, ${ }^{17}$ and amtamahamātras (F), that is, officials living far away from the centre at the edges of the empire who more or less go their own ways.

One of the key-words in PE I ostensibly being dharma, in PE II the emperor deals with the question of what dharma is: dharma involves actions which bring little "influx" (apassinave) and much virtue ( $k a$ yāna,${ }^{18}$ such as compassion, liberality, truth and purity. Next, he enumerates three types of action undertaken by him in this line. Thus, he says, he has bestowed many kinds of gifts of vision (cakhudane [D]) and has shown many types of compassion (anugahe) to men and animals, including sparing their lives (pānadākhinā $[\mathrm{E}]$ ); he concludes $(\mathrm{G})$ that writing this dharma-edict itself is yet another part of the same policy.

In the third Pillar Edict the emperor provides a list of counter-productive actions, that is, actions which cause "inflow" (äsinavagāminni $[\mathrm{F}])$. He does so because people in general have great difficulty in recognizing (and acknowledging) their bad deeds (C). One of the key-words in this edict is the verb dekh- "to see, to regard". It occurs in B (kayānammeva dekhati), C (no mina pāpam dekhati), D (dupațvekhe), E (hevam cu kho esa dekhiye), and G (esa bātha dekhiye). Given the pivotal role played by this verb one may rightfully ask if it is not this edict which the emperor anticipated when in the preceding edict he mentions that he had made the cakhudane. Indeed, one cannot escape from the impression that the edicts III-VI elaborate the programme announced in II. For, if PE III indeed provides an elaboration of the "gift of the eye", PEs IV and $V$ deal with compassion towards men and animals, including sparing their lives. And, as we will see, PE VI deals among other things with the effects of edicts, the third point specified in PE II.

However, if this is so, the set IV-VI elaborates yet another point, namely one already made in PE I. Thus, while in PE I the emperor mentions the role played by his officials in the execution of his dharma-

17 For the pulisa, see also what I have said above, p. 13, n. 13.

18 I take apāsinave bahukayāne $(\mathrm{C}$; bahukayāne as a compound, with Bloch 1950: 162) as providing a general characteristic of dharma, and what follows (day $\bar{a}$ dāne sace socaye) as a list of specific items. Compare PE III (F), in which first we have imāni āsinavagāmini nāma and then a list of sins: atha (Skt. yathō "such as, for instance") camdige, nithūliye ... 
policy, IV deals explicitly with delegation. At the same time, in IV as well as in $\mathrm{V}$ he indicates several concrete measures he did not want to leave to the discretion of the local administrators but had introduced himself. Something similar is seen in PE VI. As said, in PE I the emperor mentions the role of instruction in the fostering of the desire and lust for dharma. As suggested, it is not unlikely that he is referring to instruction through edicts here. If so, in PE VI he is returning to that, in the sense that according to him, writing edicts is not enough for fostering the dharma but requires in addition his personal attendance as well.

In PE IV the emperor notes that in matters of rewards and punishments he has given the lajūkas a free hand (atapatiye me kate, D; see also $J$ ) so that they will be able to work confidently and fearlessly towards the welfare and happiness of the people dependent upon them. At the end of the edict, however, the emperor specifies the space in the political arena which he claims for himself:

[L] My direct, personal involvement $(\bar{a} v u t i)^{19}$ goes so far: to people who have been imprisoned, have gone through the judicial process and have (finally) been convicted to death, three days are given by me as a yote.

Whatever the meaning of the word yote may be, it is clear that what is meant here is a three-day stay of the execution. As such, we are dealing

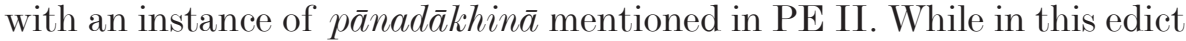
it concerns the "gift of life" to men, PE V elaborates the gift of life made to animals. ${ }^{20}$ Again we seem to be dealing with measures which he did not leave to the discretion of the local authorities but introduced himself: "By me the following species (of animals) are declared inviolable" (B).

PE VI reads as follows:

[A] devānampiye piyadasi lāja hevam ahā

[B] duvādasavasa abhisitena me dhammalipi likhāpitā lokasā hitasukhāye se tam apahața tam tam dhammavadhi pāpovā

[C] hevam lokasā hitasukhe ti pațvekhāmi atha iyam nātisu hevam patiyāsamnesu hevam apakaṭesu kim am kāni sukham āvahāmī ti tatha ca vidahāmi

19 The exact meaning of the term ävuti, which occurs here as well as in SE I (Dh. J, J. K) and SE II (Dh. M, J. N), will be dealt with in the forthcoming article mentioned above, p. 13, n. 12. There I will also attempt an interpretation of the following sentence M, which involves, among other things, a new interpretation of the form nāsamtam.

${ }^{20}$ See PE II E: dupadacatupadesu .... vividhe me anugahe kate a pānadākhināye. 
[D] hemevā savanikāyesu pațivekhāmi

[E] savapāsaṃd̄a pi me pūjitā vividhāya pūjāyā

[F] e cu iyam atanā pacūpagamane se me mokhyamate

[G] saduvīsativasa abhisitena me iyam dhammalipi likhāpitā

First I would like to take a closer look at the sentences A and B, which seem to form a section in themselves. The first thing to note is the absence of iyam in B. Thus, where PE I B, IV B, and the very last sentence of the edict under discussion read saduvisativasa abhisitena me iyam dhammalipi likhāpitā, in PE VI B we have duvādasavasa abhisitena me dhammalipi likhāpitā. I think that Hultzsch is correct in translating : "(When I had been) anointed twelve years, rescripts on morality were caused to be written by me", that is, the emperor refers to the activity of writing edicts here, not to the writing of this particular edict. The latter he does in sentence $\mathrm{G}$, in which we find iyam again: saduvisativasa abhisitena me iyam dhammalipi likhāpitā.

The grammar of the second part of B, se tam apahaț $\operatorname{tam}$ tam pāpovā, is problematic. In the first place we have the sequence se tam ... tam tam, and secondly we have the curious form $p \bar{a} p o v \bar{a}$. As regards the sequence se tam ... tam tam, it should be noted that this is the only instance of the combination se tam in the corpus of the Aśoka inscriptions. As far as I can see, we seem to be dealing with a variant of tam tam, and we have to do with a sequence corresponding to Sanskrit tad tad... tad tad "here and there ... here and there". If so, pāpovā, which in one way or the other has been derived from prāpnoti (Bloch 1950:

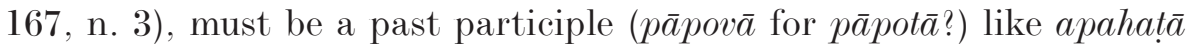
(Skt apahrtā). The question that arises is what is the subject of apahat $\bar{a}$. Theoretically it could be the dhammalipi mentioned in the preceding part. Most likely, however, it is feminine dhammavadhi found with $p \bar{a} p o v \bar{a}$. Sentences A and B may conformingly be translated as follows:

[A] King Devānampiya Piyadasi says ${ }^{21}$ thus:

[B] In the twelfth year after my anointment dharma-edicts have been ordered by me to be written for the good and welfare of the people. Here and there (the growth of the dharma) has been aborted, here and there the growth of the dharma has been realized. ${ }^{22}$

21 For $\bar{a}$ ha having the present tense, see Goodall 2001: 109, n. 9.

22 The interpretations of Hultzsch and Bloch of the second part of sentence $\mathrm{B}$ differ considerably from the one given by me above. I would like to quote these 
Interpreted in this way sentences A and B imply that in the attempt to foster the dharma writing edicts is not sufficient, as the message is not taken up everywhere in the same way. And indeed in the following sentences the emperor insists on the importance of his personal interference in the lives of his subjects:

[C] Knowing that [this promotes] the good and the welfare of the people, I look after each individual (pati) group: in the same way as [I look after] my relatives, [I look after] the people living close by and those living far away. And, knowing how I can bring happiness to each and every one, I arrange things accordingly. ${ }^{23}$

[D] In exactly the same way I look after all the individual (Buddhist) groups.

$[\mathrm{E}]$ And also all heretics are honoured by me with various forms of honour.

[F] However, a personal visit to (or: joining the ceremonies of) each (of these groups), is considered by far the most effective (thing) I can do.

[G] In the twenty-sixth year after my anointment this edict was caused by me to be written.

If my interpretation of the first six Pillar Edicts is correct, then, as in the case of the Rock Edicts, we are dealing with a compilation of carefully selected edicts. This finding has far-reaching consequences for our interpretation of the inscriptions. One of the more obvious consequences, to be discussed in the following, is the necessity of maintaining a clear distinction between the edicts and the inscriptions.

scholars' translations without further comments. Hultzsch (1925: 129) translates: "rescripts on morality were caused to be written by me for the welfare and happiness of the people, (in order that), not transgressing [aprahrtvā] those (rescripts), they might attain a promotion of morality in various respects"; and Bloch (1950: 167): "Quiconque le [the edict H.T.] respectera [a-prahartā] doit obtenir de façon ou d'autre le progrès dans la Loi".

23 Compare Hultzsch 1925: 129 ("(Thinking): 'thus the welfare and happiness of the people (will be secured)', I am directing my attention not only [atha iyam] to $(\mathrm{my})$ relatives, but to those who are near and far, in order that [kimam] I may lead them $[k \bar{a} n i]$ to happiness, and I am instructing (them) accordingly") and Bloch 1950: 167-168 ("Voici comment j'entends le bien et le bonheur du monde. Comme pour mes parents, pareillement les proches et les lointains, je veux procurer à certains le bonheur, et prends des mesures en conséquence"). 


\section{Edicts verisus Inscriptions}

Until now, scholars do not seem to have distinguished between the edicts and the inscriptions. The edicts are taken to have been specifically composed for the inscriptions. Thus, the word lipi, with which the edicts refer to themselves, has often been translated with "inscription". See, for instance, Alsdorf's translation (1962: 37) of SE I (Dh. N) iyam ca lipi ... sotaviyā with "Und diese Inschrift ist ... zu Gehör zu bringen". However, if the Rock and Pillar Edict series are indeed compilations we have to do with selections out of a corpus of existing documents. The word lipi found in the edicts should then be taken to refer to the original document, the function of which need not necessarily be to provide the content for an inscription. ${ }^{24}$ In this connection I would like to refer to Separate Edicts I and II, in which the local authorities are enjoined to have the documents (lipi) read aloud on the Tisya day at the beginning of every new season..$^{25}$ It is indeed not very likely, or at least there are no indications, that the communal or administrative meetings referred to here took place on the hilltops or slopes where the two inscriptions are found..$^{26}$ Moreover, the passage referred to just now, which mentions the reading aloud of the text during communal meetings, is followed by another that states that every mahāmatra should read the text to himself whenever he cares to. ${ }^{27}$ This passage evidently

${ }^{24}$ Already here I wish to make an exemption for the word lipi in RE XIV and in PE VII, in which cases it does seem to refer to the inscription. For the nature of PE VII, see below, p. 27f. and 32f. For RE XIV, see above, p. 9.

${ }^{25}$ SE I (Dh. N): iyam ca lipi anucātummāasam tisena nakhatena sotaviyā, "Und diese Inschrift [sic] ist alle vier Monate, wenn der Mond im Hause Tișa steht, (allen Beamten) zu Gehör zu bringen" (Alsdorf 1962: 37). The corresponding passage in Jaugada $(\mathrm{O})$ reads: iyam ca lip̄ anucātummāsam sotaviyā tisena. See also SE II (Dh. V): iyam ca lipi tisanakhatena sotaviya and the corresponding passage in Jaugada (W): iyam cā lip̄ anutisam sotaviyā.

${ }_{26}$ Mountains carry associations completely opposite to the concept of community. Mountains are a no man's land, at least from the point of view of the community. As such, they are synonymous to the frontier. That is why the Rock Edict inscriptions, which, as I will try to show, were intended to be placed at the boundaries of the empire, are found on mountains or boulders (miniature mountains), also in Girnār, Dhauli and Jaugada, where the real boundaries are formed by the ocean.

${ }_{27}$ SE I (Dh. O): kāmam cu khanasi khanasi aṃtalā pi tisena ekena pi sotaviyā, "nach Belieben ist sie aber auch zwischen den Tisya-Tagen, sooft sich die Gelegenheit bietet, auch nur einem Einzelnen zu Gehör zu bringen" (Alsdorf 1962: 37). Cp. Jaugaḍa $(\mathrm{P})$ : amtalā pi ca sotaviyā, khane samtam ekena pi sotaviyā. 
makes more sense in the case of, for instance, a letter kept in an archive than that of an inscription situated in a "public" place.

As I see it, we have to do with original letters of the emperor which had been addressed to the local authorities. Note in this connection the opening sentences in the Separate Rock Edicts, e.g. SE I (Dh. A): devānampiyasa vacanena tosaliyam kumāle mahāmātā ca vataviya, "Auf Anordnung Seiner Majestät ist dem Vizekönig und den Mahāmātras zu Tosali kundzutun" (Alsdorf 1962: 36). The vice-king and the Mahāmātras are ordered to have the text read aloud during the communal gatherings organized by them. Examples of such ceremonies are the day of the settling of the accounts in the royal aksapatala hall (described in the Arthaśāstra) and the Buddhist uposatha (see Tieken 2000: 11-13). In either case, we are dealing with acephalous organizations, in which every individual member, as a co-sharer (mahāmātra and bhikkhu respectively), had a voting right, or rather, had a right to put his ideas before the meeting and to try to win the agreement of the other members. The purpose of the meetings was to report of one's activities of the past year (or season or month) and to establish the conditions for future collaboration. The sending of letters such as preserved in the Separate Edicts to the local leaders at Tosalī (Dhauli) and Samāpā (Jaugada) and the request that they have these letters read at the communal gatherings seem to represent an attempt by an outsider to establish control over the respective communities. As for the local leaders, their having the letters read at the meeting implies acceptance of the sender as an important member of the community and agreement with his ideas concerning government and administration. As such the missives played a role in the attempt to establish control, however nominal, over an area extending far beyond the nuclear area over which the king was able to exercise direct control through his personal presence; they betray the king's imperial aspirations.

Whatever may have been the exact function of the original documents, I think we would do well to maintain a rigorous distinction between these original documents and the inscriptions, which represent their secondary use. This situation raises a number of questions. One of these concerns the time elapsed between the composition of the original documents and their compilation. This question becomes most obvious if we compare the Rock Edicts with the Pillar Edicts. It is generally assumed that the Rock Edicts hail from the earlier period of the emperor's reign and the Pillar Edicts from the later period. This 
assumption has been based on the dates mentioned in the texts, which, however, seem to belong to the original documents. As such they do not provide information on their compilation and engraving, which may have taken place many years later. In this light the relationship between the two sets of inscriptions will have to be considered anew, in which some of the findings made above concerning the differences between the two sets will play an important role. Another question concerns the function of the inscriptions, that is, the purpose of making compilations of existing documents and having them engraved on rocks and pillars. A related question concerns the role of Aśoka, who has been generally credited with the composition of the texts of the inscriptions. Among these problems I will also discuss the evidence which suggests that the edict series were accompanied by colophons which provided specifications concerning the engraving of the inscriptions.

\section{The relationship between the Rock Edicts and the Pillar Edicts}

As far as I am aware, the question of the relationship between the Rock Edicts and the Pillar Edicts has not to date been explicitly dealt with. I have the impression, however, that the Rock Edicts, the edicts as well as the inscriptions, are generally believed to belong to the first part of the emperor's career and the Pillar Edicts to the later part. ${ }^{28}$ The tacit assumption is that in the course of his reign the emperor switched from engraving edicts on rocks to engraving them on pillars. Thus, while the "dates" found in the Rock Edicts do not go beyond the thirteenth year, the PEs I-VI are indeed all issued as late as the twenty-sixth year of the emperor's reign; there is a seventh Pillar Edict, found only in DelhiTōprā, which was issued one year later.

In this connection I would like to turn to the nature of the dates mentioned in the Rock Edicts. As already noted above, of the fourteen Rock Edicts only the fourth was formally dated: the text was drawn up in the twelfth year of the emperor's reign ( $\mathrm{RE} \mathrm{IV} \mathrm{K).} \mathrm{As} \mathrm{indicated,} \mathrm{years}$ are mentioned in some other edicts but these are part of the message. Thus, in III it is mentioned that in his twelfth year the emperor ordered that inspection tours were to be held (RE III B-C), and in V that the emperor prides himself on the institution of the office of dhammama-

28 See, for instance, Andersen (1986: 85), who notes that "me als Agens vorwiegend in den späteren Säuleninschriften verwendet wird” (italics mine). 
hāmatta in his thirteenth year (RE V I). However, in either case these dates need not be those of the respective edicts, which may have been issued many years later. This situation is even clearer in the thirteenth edict in which the emperor, after having mentioned the conquest of Kalinga in his eighth year, continues with "then, later, now that the country of the Kalingas has been (completely) taken" (RE XIII C: tato

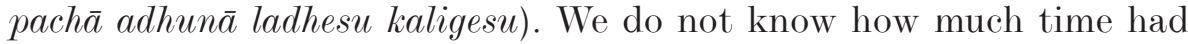
elapsed between the eighth year and "now", that is, the year in which the edict was drawn up. To that we would now have to add the time elapsed between the composition of the edict and the compilation of the edict series.

Contrary to the Rock Edicts, the first six Pillar Edicts are all dated in one and the same year, namely the twenty-sixth year of the emperor's reign. If it is supposed that this was also the year in which the Pillar inscriptions were engraved, it will be clear from the foregoing that the rock inscriptions cannot be much older than those on pillars. In fact, I think we should seriously reckon with the possibility that the two sets of inscriptions were engraved more or less simultaneously.

I would like to draw attention to the division of labour between the two edict series, each of which, as we have seen, has a programme of its own. Thus, as argued above, the Rock Edicts IV-XIV seem to have been selected mainly as samples of edicts. As such the series shows a concern with the phenomenon of edicts in government rather than with the contents of the particular edicts. This impression is further strengthened by the fact that the majority of edicts have not been dated and as such are presented out of context. By contrast, the first six Pillar Edicts are dated in the same year, which, while providing a temporal context, draws attention to the contents of the edicts and the implementation of the measures mentioned in them. Furthermore, after having acknowledged the difficulties his officials and subjects might have in living according to the dharma, in the Pillar Edicts the emperor provides clear guidelines. Some of the measures mentioned in the Pillar Edicts are indeed of a strikingly concrete nature, certainly if they are compared to the admonishments given in the Rock Edicts, which are mainly concerned with general ethics and life in the hereafter. Reference may be made here to the list of animals one is forbidden to maim or kill on certain festive days given in PE V. At the same time, in addition to edicts good and effective government is said to require the personal presence and active interference of the ruler in the local 
affairs. As said, with this the Pillar Edicts present a picture which is entirely different from that emerging from the Rock Edicts, which deal, among other things, with ruling from a distance and conquest through conversion.

A similar type of distinction may be seen if we compare the Minor Rock Edicts - found on rocks - with the Schism Edict - found on pillars. Both the Schism Edict and the Minor Rock Edicts each in their own way deal with the emperor's involvement in the affairs of the Buddhist samghas. However, in the Schism Edict the emperor provides concrete legal aid to the samgha with regard to how to deal do with monks exhibiting disruptive behaviour (see Tieken 2000). The Schism Edict contains a legal formula and specifies exactly the tasks of the various parties involved in the case of the threat of schisms. By contrast, MRE I lacks any concrete message. Instead, the emperor is basically concerned with his image, in this case that of a Buddhist monarch, describing his activities in terms derived from the lives of wandering monks. ${ }^{29}$

This distinction, or rather, contrast, between the Rock and Pillar Edicts may be explained with reference to their locations. While the Pillar Edicts are found in the middle of the realm in the Ganges basin, the inscriptions on rocks (the Rock Edicts as well as the majority of the Minor Rock Edicts) are found far removed from the centre at its very edges. As such they were addressed to people living outside the emperor's direct control. While these people, unlike those addressed in the Pillar Edicts, could not be regularly visited by him, let alone be conquered, they could be brought over by persuasion. One of the means of achieving this would have been to take care that they at least heard of royal policy and, for instance, the way in which the subjects and officials are instructed. Note in this connection RE XIII S:

ata pi dūtā devānampiyasa no yaṃti, te pi sutu devānampiyasa dhaṃmavutam vidhanam dhammōnusathi dhammam anuvidhiyaṃti anuvidhiyisaṃti ceva,

And where the messengers of the Beloved of the Gods do not go, the people living there, having heard ... the dharma-instruction of the Be-

29 It cannot be coincidental that these two edicts, the Schism Edict and the Minor Rock Edict, which have been disseminated individually and are not part of a series, are concerned in a direct way with the affairs of the samgha. Admittedly, also RE VIII refers to a visit by the emperor to Sambodhi, the place of Buddha's enlightenment, and in PE VI it is said that one should regularly visit the various sects in the realm. On the other hand, the term samgha, and for instance also that of upassaka, is found only in the two edicts under discussion. 
loved of the Gods, will live according to that instruction and will remain doing so in the future.

Leaving aside for the moment the question of wether the Pillar Edicts were indeed immediately engraved, as argued above (p. 22), the time gap between inscriptions on rock and those on pillars may have been much less than the dates found in them might at first sight suggest. In fact, the complementarity of the two sets of edicts suggests that their dissemination and engraving was part of an activity coordinated from one and the same centre. At this centre, the capital, one would have followed two different strategies depending on whether the inscriptions were to be directed to the people living at the faraway borders or to those living in the centre of the realm.

\section{The Evidence of Colophons}

As stated, the Rock Edicts are found on rocks (or stone slabs) situated on the outskirts of the empire and the Pillar Edicts on pillars in the central locations. There are no cross-overs, except in the far northwest. ${ }^{30}$ Combined with the fact that no Rock Edicts are found at frontiers within the realm, ${ }^{31}$ that would suggest that with the dissemination of the texts and their engraving we are dealing with one and the same well-coordinated activity. As I have tried to show, the Rock Edict and Pillar Edict series differ considerably in tone and contents. Nevertheless it is doubtful that this difference alone could at all times have prevented a text which was meant to be engraved on a boulder on the outermost frontiers from being engraved on a pillar placed somewhere in the middle of the realm, or vice versa. Given this situation, it is not unreasonable to expect that the texts were accompanied by colophons with specifications as to their engraving. If so, these colophons were

30 In the extreme northwest, the text of PE VII (in Middle Indic in the Aramaic script with the Aramaic translation interspersed) has been found on a slab (Kandahār II; see Benveniste 1966, Shaked 1969), which is the functional equivalent of a rock or mountain. In Taxila an Aramaic version of RE IV is found on a pillar. Note that the Lampāka (Pul-i Daruntā) inscription is found on a slab, while the text ends with the (fragmentary) instruction: "There were ordered to be written on pillar[s of stone.... these injunctions which] we have made known [for the benefit of those that will come] after us" (Henning 1950: 87; see also Shaked 1969: 122).

${ }^{31}$ Admittedly, some versions of the Minor Rock Edicts are found in the "centre" of the realm as well; see Allchin - Norman 1985. 
naturally omitted from the inscriptions. However, we do come across a few passages in the edicts themselves that contain orders concerning the inscribing of the texts. A closer look at these passages would suggest that we might have to do with the texts of colophons, which, however, somehow came to be incorporated into the texts of the edicts proper.

The first instance to be discussed is found in MRE I. The end of the Rūpnāth version of MRE I reads as follows:

$[\mathrm{J}]$ etiya athāya ca sāvane kate

[K] khudakā ca udā̄ à ca pakamamtu ti

[L] aṃtā pi ca jānaṃtu

[M] iyam pakame ca kiṃti cirathitike siyā

$[\mathrm{N}]$ iyam hi ațe vadhim vadhisiti vipulam ca vadhisiti avaladhiyenā diyadhiyam vadhisiti

[Q] iyam ca aṭe pavatisu lekhāpetaviye ti hidha ca athi silāthambhe silāthambhasi likhāpetaviye ti

[R] etenā ca vayamjanenā yāvatake tuphākam āhāle savata vivasetaviye ti

[S] vyuthenā sāvane kațe 200506 sata vivāsā ti

Among the many versions of the Minor Rock Edicts, the instruction concerning engraving $(Q)$ is peculiar to Rūpnāth, Pāngurāiāa and Sahasrām only. $R$ is found only in Rūpnāth, but is a variant of the Schism Edict (Sarnāth I): āvate ca tuphākam āhāle savata vivāsayātha tuphe etena viyamjanena). In Rūpnāth the instructions (Q) are found within the text of the edict. By contrast, in Sahasrām and Pāngurāriā the corresponding text is found at the very end, namely after Rūpnāth's R-S, which occurs immediately after N. Sahasrām reads as follows:

$[\mathrm{J}]$ se etāye ațāye iyam sāvane

[K] khudakā ca uḍ̄āā ca palakamaṃtu

[L] aṃtā pi ca jānaṃtu

[M] cilathitīke ca palakame hotu

[N] iyam ca ațe vadhisati vipulam pi ca vaḍisati diyāthiyam avaladhiyenā diyadhiyam vadhisati

[O] iyam ca sāvane vivuthena

$[\mathrm{P}]$ duve sapamnnālātisatā vivuthā ti 200506

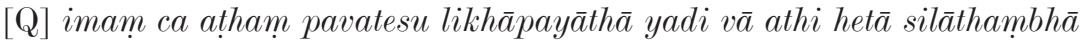
tata pi likhāpayātha ti 
In Pāngurāariā the text corresponding to Sahasrām O-P (Rūpnāth S) is missing (Andersen 1990: 73-77).

I have argued elsewhere (Tieken 2000: 25) that sentences Q and R in Rūpnāth represent an interruption of the original text, in which $\mathrm{S}$ followed upon N. Thus, the order of the lines in Sahasrām would be more original than the one in Rūpnāth. This dragging around of the text in combination with the fact that the instructions concerning the engraving are absent from all other versions of the edict suggests that we have to do with a later intrusion. What might have happened here? As I see it, the text originally ended with a sentence like vyuthenā sāvane kate 200506 sata vivāsa $t i$ (Rūpnāth). Note the quotation particle (i)ti at the end, a usage taught in Arthaśāstra 1.2.22 and common in other early inscriptions as well. ${ }^{32}$ At some point the verb vivas- in vivuthena and vivass $\bar{a}$ ("this proclamation was made by me after I had been away from home / after an absence from home for 256 nights") was misunderstood as somehow referring to the dissemination of the edict. In this connection I would like to refer to vivāsayātha in the Schism Edict (Sarnāth I): āvate ca tuphākam āhāle savata vivāsayātha tuphe etena viyamjanena). ${ }^{33}$ As I attempted to show earlier (Tieken 2000: 4-7), this causative of vivas - is actually an emendation, through unattested visvāsay-, of visvamsay-, which in its turn was an emendation of visamsay-, when the derivation of the latter word from Skt viśams- "to recite" was no longer clear. The emendation vivassayātha (see also vi$v \bar{a} s \bar{a} p a y \bar{a} t h \bar{a}$ in Sarnāth J) was based on a meaning "to dispatch, disseminate", which was abstracted from the causative of vivas- "to cause [the document] to live abroad". ${ }^{34}$

32 For instances of śăsanas ending in (i)ti, see, e.g., nos. 58, 69, 89, 98 (1), 100 (98.3), 101, 102 and 104 in Sircar 1993. See also, for instance, the Eran Stone Pillar Inscription of Budhagupta of the year 165, no. 39 in CII III (p. 339-341), and the Stone of Kalasan for Java in Sarkar 1971: 36. On this use of $i t i$ in the inscriptions under investigation, see also Caillat 1966. The particle iti at the end of RE XIV may represent a different use, namely that of $i t i$ at the end of an enumeration (see, e.g. Arthaśāstra 2.3.4 and Stein 1935: 474-475).

33 Hultzsch's translation of this sentence runs as follows: "And as far as your district (extends), dispatch ye (an officer) everywhere according to the letter of this (edict)" (Hultzsch 1925: 163). For Hultzsch's addition of an officer as object to vivas- rather than of edicts, see Tieken 2000: 5. See also vivāsite in Nițūur R: [savapa] thaviyam ca vivā [si]te ti yath $\bar{a}$ rā $[j] \bar{a}$ asoko $\bar{a} h \bar{a}$ tath $\bar{a}$ ti (Andersen 1990: 68).

34 The "origin" of the verb vivāsay- "to dispatch, disseminate" seems to go back to the Schism Edict, where it can be explained as the final outcome of a series of corruptions which ultimately go back to the failure to grasp the derivation of 
In this way MRE I came to include information about the dissemination, which in some versions then led to the incorporation of the colophon itself into the text of the edict proper.

Other evidence of a colophon may be found in the Seventh Pillar Edict. This inscription is found only in Delhi-Tōprā, where it was engraved only after the pillar with the first six edicts had already been erected. While the first six edicts were dated to the twenty-sixth year, the seventh is dated to the twenty-seventh. Apart from all this, we seem to be dealing with a curious text.

Compared to the Rock Edicts, PEs I-VI are characterized by a stricter format; each new edict begins with the words (leaving aside minor spelling differences) devānampiye piyadasi lājā hevam āha. In this way the Pillar Edicts betray a great concern with the authentication of each statement. In the first, fourth, fifth and sixth edicts this line is followed by saduvisativasābhisitena me iyam dhammalipi likhāpitā or similar words. The same line is found at the end of the sixth edict, formally closing the series. ${ }^{35}$ Furthermore, if not in all versions, each edict, except for the fifth, is concluded by the quotation particle $t i$, for which, see above, n. 32.

Taking our cue from the words devānampiye piyadasi lājā hevam āha (A, O, Q, X, BB, FF, II) and etam devanampiye piyadasi lājā hevam àha (C, I, RR) the Seventh Pillar Edict falls into nine (or ten) individual edicts. As such it closely resembles the text of a series of edicts such as the Pillar Edict series. If the Seventh Pillar Edict was indeed intended as a series of edicts, the proper end of the Seventh should be QQ, the

visamsay-. It follows that the authors (or editors) of the text of MRE I were familiar with, and influenced by, the text of the Schism Edict as preserved in Sarnāth. Other evidence of this influence is Rūpnāth $R$, which is a variant of Sarnāth I (see above).

35 Note that PE VI B contains another number, not " 26 " but "12" (duvādasa $)$. In PE V B instead of iyam dhammalipi likhāpitā is found imāni pi jātāni avadhiyāni katāni. The occurrence of these sentences at the beginning of the edicts coincides with the division in Delhi-Tōprā of the text into four columns. The text of each column is between 20 and 22 lines long, except for the one on the east face, which is only 10 lines long. This "unevenness" would show that the ornamental division of the series in four columns had not been intended by the editors of the series. In some other versions the six edicts have indeed been engraved one below the other. In Delhi-Tōprā the empty space below the sixth edict has been filled in by the first part of the so-called Seventh Pillar Edict, which after line 21 continues round the pillar. These points have been discussed earlier by Norman 1987. 
reference to the year the edict was issued in: satavisativasābhisitena me iyam dhammalibi likhāpappita $t i{ }^{36}$ Indeed, there is some evidence suggesting that the text that follows (RR-SS), which enjoins the Edict's engraving, was only secondarily provided with the status of an edict. Note in this connection especially the abbreviated form of the introduction, which instead of the complete series of titles has only dev $\bar{a}$ nampiye: ${ }^{37}$

[RR] etam devānampiye āha

[SS] iyam dhammalibi ata athi silāthambhāni vā silāphalakāni vā tata kațaviyā ena esa cilathitike siyā.

I think we should reckon with the possibility that the Seventh Pillar Edict indeed represents the reproduction of the text of an edict series, such as at the time may have circulated in the local administrative centres. The almost surreptitious way in which the final part (SS) was turned into a proper edict suggests that such texts included instructions concerning the engraving. During the engraving of the Seventh Pillar Edict the latter instruction was at the last moment transformed into an edict by providing it with a proper introduction.

MRE I and PE VI thus seem to testify to the existence of texts of edicts or edict series which included colophons with instructions concerning the medium on which the texts were to be engraved. ${ }^{38}$ However, on one point the evidence does not provide an answer. The two

36 It is difficult to assess the function of final $t i$. The particle could mark the end of an individual edict, a use found in the Pillar Edicts I-VI, or indicate the end of the text as a whole (see above, n. 32). However, it could also anticipate etam in the following etam devānampiye $\bar{a} h \bar{a}$; cf. H-I: ... dhammavadhiya ti etam devānampiye piyadasi la $\bar{a} \bar{a} \bar{a} h \bar{a}$, "How could I elevate them by the promotion of morality? Concerning this, king Dēvānāmpriya Priyadarśin speaks thus" (Hultzsch).

${ }^{37}$ The implication of the peculiar mark found on top of the syllable de of devānampiye, for which, see Hultzsch (1925: 133, n. 6), is unclear. Hultzsch remarks that a similar mark was found above the word athaye in $\mathrm{OO}$, on the basis of which he concluded that the writer of the inscription wanted us to place RR and SS before OO. If so, this mark would have nothing to do with the abbreviated form of the introductory formula.

38 Also in Dhauli and Jaugada a reference is found to the medium on which the texts have been engraved, in the given case on "mountains". Thus, inbetween the opening words of RE I iyam dhammalip̄ and devānampiyena priyadasinā lājin $\bar{a}$ likhāpitā have been added the words khepi $[m]$ galasi pavatasi (Jaugada). In the Dhauli version the greatest part of this line is unreadable except for [si pava]tasi. We are almost certainly dealing with a local addition here. 
available examples of colophons, from MRE I and PE VII, appear not to discriminate between pillars and rocks (or stone slabs), mentioning both possibilities. Apart from the fact that this did not affect the final choice - all Minor Rock Edict versions are found on rocks and the Seventh Pillar Edict is found on a pillar ${ }^{39}$ - this can hardly represent the original situation. That is to say, if the texts had been accompanied by instructions concerning their engraving, we may expect that these would have been clear and unambiguous. In order to understand the reference in the available colophons to rocks (or slabs) as well as pillars, we should, however, take into account the circumstances under which the available colophon texts were preserved. They were preserved only because for some reason they had come to be incorporated into the edict proper. However, in the context of the edict it is no longer a matter of engraving this particular edict. Instead, the emphasis is on the dissemination of instructions through edicts engraved wherever it is appropriate. What originally were two different colophons may have come to be combined here for the sake of completeness.

As can be seen, the (pseudo-)colophons only mention the medium, that is, stone pillars, stone slabs, and mountains. As such they cannot account for the fact that the Rock Edicts are found only at the fringes of the realm and that not even one stray Rock Edict is found in the middle of the realm. "Mountains" (or frontiers) within the realm have been ignored completely. This seems to point to the conclusion, at least as far as the Rock Edicts are concerned, that the text was probably received at each site directly from the centre. In this connection it should be noted, however, that the dissemination of the Rock Edicts has taken place in two consecutive rounds. First the series (Schneider's $\mathrm{p}^{2}$ version) was sent to the north and northwest (Kālsī and Mānsehrā and Shābāzgaṛī respectively) and the south (Erragudii). Only after a revision was the text (Schneider's $\mathrm{p}^{1}$ ) sent to the west (Girnār) and the east (Dhauli and Jaugada). Even so, the time gap between the two rounds must have been short as the persons responsible for the dissemination of the texts to the west and east were apparently still well acquainted with the criteria involved in the dissemination, with Rock Edicts on rocks and Pillar Edicts on pillars. Most likely the second round was not an afterthought, but had been planned from the very beginning. In any case, it fills in the gaps left open in the east and the

39 That is, except in the northwest, where the text of PE VII has been found on a stone slab; see above, n. 30 . 
west after the $\mathrm{p}^{2}$ version had been sent to the north, the northwest and the south. Only with the $\mathrm{p}^{1}$ version were all directions covered. ${ }^{40}$

What is striking, though, are the "liberties" taken with the text by the persons responsible for the revision of the $p^{1}$ version. The revision is not restricted to individual words or forms but includes whole passages as well. A case in point is found in RE IX, in which the last part has been replaced by what looks like a variant of $\mathrm{RE} \mathrm{XI}$, which latter edict has actually become more or less redundant through this substitution. While it is difficult to identify retrospectively a compelling reason for this substitution, it follows that the texts of the edicts were not sacrosanct and could be adapted and manipulated by the compilers of the series.

Another instance of such a wholesale adaptation of the text is found in the Schism Edict of Sarnāth. As I argued at an earlier occasion (Tieken 2000: 7-10), the problematical words dhuvāye and posathaye in sentence $\mathrm{H}$, anuposatham ca dhuvāye ikike mahāmāte posathāye yāti, might well be later insertions borrowed from the phrase patipadaye dhuvāye cā anuposatham of PE V (Delhi-Tōprā H). To all this may be added the corruptions visvamsayitave and vivassayātha from that same Sarnāth inscription. As already noted above, ${ }^{41}$ visvamsayitave appears to be the result of the attempt to emend visamsayitave once its derivation from visamsay- "to cause to recite" had somehow been lost sight of. Next, the "emendation" visvamsayitave was itself emended into vivassay( $\bar{a} t h a)$. The final result was that the passage as a whole came to be considered a colophon giving instructions concerning the dissemination of the text, which would explain its omission in the Kausāmbī and Sāñci versions of the edict. At the same time, the omission of the part

40 Note that the "chronological order" of the $p^{2}$ and $p^{1}$ versions agrees with the order of appearance of the people concerned in the Rock Edict series: the addressees of the "earlier" $p^{2}$ versions are mentioned in RE II, which specifies the people living on the northwestern and the southern borders; those of the "later" $\mathrm{p}^{1}$ versions occur in the definition of the realm given in RE XIII, which enumerates, for instance, the Bhojas, which is a name with a definitely western ring, and the Kalingas from the east. However, it cannot be concluded from this that the persons responsible for the first round in the dissemination of the texts had not yet considered the second round as well, because RE XIII was already available to them.

${ }^{41}$ See p. 26, and also Tieken 2000: 4-7. The identification of this corruption is the only point from this article with which Wright seems to agree with me in his study of MRE I-II (Wright 2000: 332). 
of the text concerned in Kauśāmbī and Sāñcī would show that the corruption goes back to the so-called archetype of the various versions.

On the basis of all the evidence discussed so far it is not unreasonable to conclude that the compilers of the texts of the inscriptions were working with old documents, which must have been lying in the archives for already quite some time. In addition to the fact that some details of the texts were no longer clear to them, the compilers of the texts allowed themselves considerable freedom in adapting or revising the edicts. In the end, it is not unlikely that at the time of the compilation the ruler in whose names the edicts had been issued was no longer alive.

In what follows I would like to elaborate upon this conclusion and discuss the image of the emperor projected in the inscriptions, the time lapsed between the original edicts and the inscriptions, and the relationship of the historical emperor Aśoka to the inscriptions.

\section{The Inscriptions as Monuments}

As stated above, in the inscriptions we seem to be dealing with old letters which had already for some time been lying in the archives. Evidently the inscriptions were not supposed to replace these letters or to take over their function. In fact, the emperor who had ordered the original letters may already have been long dead. It follows that the inscriptions are a kind of commemorative monument ${ }^{42}$ erected by the

42 The inscriptions on boulders have often been considered as elements borrowed from the Achaemenids. Apart from inscriptions on buildings and seals, mostly found inside their towns, the Achaemenids have left a number of impressive inscriptions in the countryside. A case in point is Darius' famous Bisotun inscription, which is found high up on a steep cliff. While the inscription as such is visible from a far distance, it is virtually impossible to read the text. We seem to be dealing with an original, peculiar Achaemenid custom, in which mountains were held sacred, a fact already mentioned by Herodotos (Lecoq 1997: 84). Note in this connection also Darius' tomb at Naqš-e Rostam, which had been cut high up into a steep mountain side (Briant 1996: 182-183). However, I think that as far as the Aśoka rock inscriptions are concerned the agreement between the developments in Persia and India may well be purely coincidental. The "mountains" of the Rock Edicts seem to suggest the function of a boundary, the various ideas concerning boundaries having been loaded on the mountain. We are clearly dealing with an archetype or a symbol here, which as such could itself be represented again by, for instance, the single boulder at Girnār, the stone slab at Sopārā and later the hero stones elsewhere in India. 
emperor's successors or by rulers who claimed to be his successors. As monuments, the inscriptions are tributes to a great reformer and lawmaker as well as to a great political thinker.

As to the emperor's role of reformer, the key word of the new world order taught by him is dharma. Mahāmātras are transformed into dharma-Mahāmātras and liberality into dharma-liberality, which is a liberality undertaken not for any immediate benefits but for happiness in the hereafter. It should be noted that this reformation involves a complete reversal of the Hindu worldview. Whereas in Hinduism the dharma is found in the past, and in going forward it has to be retrieved, in the edicts the dharma begins with the emperor himself. In RE V C he calls himself the adikale kayyānassa, or "the one who starts to practise altruism". The past being imperfect, one cannot go backwards but only forwards, to a future which may even be better than the present time.

Letters containing instructions for the local authorities, and through them for the people, form an important instrument in this process of reformation. Even if at the time writing had been a novelty, its potentials especially in the matter of legislation were apparently grasped immediately. It should be noted that before writing had become common the law had to be formulated over and over again by the people concerned. Through being fixed in writing, the laws were kept free of any intrusions from local and contemporary interests, which enhanced their authority in solving conflicts considerably. In fact, the very fact that the legislation came from outside generally proved an advantage.

As already indicated, the references to writing in the edicts would concern the original missives, not the inscriptions. The Seventh Pillar Edict seems to form an exception. The text is concluded with the words (SS):

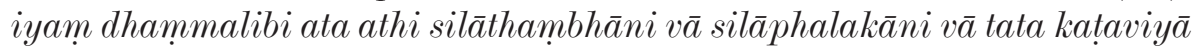
ena esa cilathitike siy $\bar{a}$, "Wherever there are stone pillars or stone slabs this dharma-document is to be inscribed, so that it (sc. the edict) is of long duration". In addition, in the middle of the text $(\mathrm{P})$ a reference is found to edicts on pillars: dhammathambhāni kațani, "dharma-pillars were made (by me)". The context suggests that we are dealing with pillars engraved with "edicts". However, the relationship of the Seventh Pillar Edict to the six of the first series is not as obvious as it might seem at first sight.

I have above attempted to show that Pillar Edict VII is a composition which imitates a compilation of edicts, including the colophon, such as 
formed by Pillar Edicts I-VI. In connection with the secondary, derived, nature of Pillar Edict VII I would like to draw attention to the "misuse" in it of a stock phrase from the Rock Edicts. The opening lines of the edict contain the phrase atikamtam amtalam, which is otherwise common in the Rock Edicts (see above, p. 10). However, where in the Rock Edicts this phrase was used to depict the author of the edict as a reformer, in Pillar Edict VII it is given an entirely different twist: ${ }^{43}$

The kings who were in times past, had this desire, that men might (be made to) progress by the promotion of morality; but men were not made to progress by an adequate promotion of morality. Concerning this, king D.P. speaks thus. ... How then might men (be made to) conform to (morality)?

The image given is that of a ruler who, however diligently, merely continues his predecessors' work. In the end, the Seventh Pillar Edict has all the characteristics of a poor imitation.

In addition to this it is clear that the Seventh Pillar Edict, which was issued in the emperor's twenty-seventh year, that is, one year after the Pillar Edicts I-VI, was not disseminated with the latter series. Pillar Edict VII is found only at Delhi-Tōprā, and while I-VI were engraved when the pillar was lying on the ground, the engraving of VII was carried out only after the pillar had been erected. The question then is who was responsible for the text of PE VII: the same persons who compiled the Rock Edict and Pillar Edict series or some later, local writer? Unfortunately, no definite answer to this question seems possible. Note in this connection the fragment of the text of PE VII on a stone slab in Kandahār, ${ }^{44}$ which suggests that we are not dealing with a text composed locally. However, if the text had indeed been distributed as widely as that of the Pillar Edicts I-VI, we would have to assume that it was no longer considered worthwhile to erect new pillars for this edict. Engraving the text on pillars already standing was not practical; its engraving on the Delhi-Tōprā pillar below the first series, carried out after the pillar had been erected, forms an exception. All this, however, seems to presuppose a change in the political situation between the Pillar Edicts I-VI and VII. This would, incidentally, suggest that the time

43 B-F in the translation of Hultzsch 1925: 133-134.

44 It is curious that in the northwest a fragment has been found precisely of this one Pillar Edict which is rare in India, while so far nothing has been found there of the "common" Pillar Edicts I-VI. 
gap between I-VI and VII was greater, if not much greater, than the single year indicated by the dates.

Finally, the inscriptions are also a tribute to a great political thinker. ${ }^{45}$ Thus, in RE XIII a veritable theory of empire is unfolded, which includes an outline of the different strategies to be employed towards the various people in the realm. In all, three types of conquest are outlined. The first consists of brutal force and involves a great loss of lives. The emperor refers in particular to his conquest of Kalinga here, which he had come to regret because of the many people killed. The second type of conquest consists of the show of a superior military force, which could serve as a deterrent to potential invaders. It is said to be particularly effective in dealings with the people living in the forests $(a t a v \bar{\imath})$. The third type of conquest is said to be specifically suitable as regards people living far beyond the boundaries of the realm, such as the Greek kings and people living even farther away. It is basically a policy of conversion.

The difference in the approaches to the atav $\bar{\imath}$, on the one hand, and the people living far away in the northwest and the south, on the other, is significant. The $a t a v \bar{\imath}$ are the people living in the forests and the uncultivated tracts of land immediately surrounding the so-called janapada. They supply forest products to the janapada but at the same time form a threat to it, carrying out raids on the richer, cultivated lands. Note in this connection Arthaśāstra 2.1.36, in which a king is advised to grant tax exemption to a land exhausted by raids of forest people (paracakrātavīgrastam ... deśam parihared rājā). As such, the atavi cannot be ignored. Every ruler, however petty, has to deal with the forest people which surround his janapada, either by negotiations or more often by the deployment of force. However, in the case of the Greek kings living far away to the northwest of the realm or the Cōlas living in the south, the use of force was not practical: they simply could not be kept in check by force or by threats. The only way open was to seek their cooperation. One of the ways to achieve this was thus to actually try to "convert" the people at the frontiers by acquainting them with the type of administration and government current in the realm.

As we have seen, the distribution of the inscriptions is in agreement with this classification of types of conquests found in the inscriptions

45 As such the inscriptions seem to forshadow a later tradition which links the legendary author of the Arthaśāstra specifically with the Maurya dynasty. 
themselves. ${ }^{46}$ Thus, the Rock Edicts, which are found at the fringes of the empire and seem to provide mere examples of edicts, present the picture of an absentee ruler whose main interest is the life hereafter. In contrast the Pillar Edicts, found in the centre of the realm, present a ruler who is prepared to interfere in local affairs directly and personally.

In this connection it may be rewarding to take a more detailed look at the Rock Edicts as documents specifically addressed to the various peoples living at the fringes of the empire. The contacts between the emperor and these peoples will have been mainly through trade. This might, for instance, explain the reference in Rock Edict II to wells dug along the roads as well as the emperor's frequently expressed concern for the welfare of wandering ascetics, who plied these same trade routes.

Another point which will have to be considered more carefully than can be done here concerns the translation of the texts of the Rock Edicts into the various local administrative languages. Why did one go to all the trouble of translating if the inscriptions are "only" monuments? I have the impression that it is generally assumed that the translations were carried out at the respective local administrative centres themselves. But in the light of the conclusions presented above concerning the dissemination of the edicts as a series dispatched in practically one go from the same centre this would not really make sense. I think we should at least reckon with the possibility that the translation was carried out in the capital, that is, in the same place where the texts have been compiled. The translation would be part of the projection of the image of a large, tolerant empire in which many languages were in use.

\section{AŚOKA}

One of the questions that remain is what the edicts or else the inscriptions have to do with the emperor Aśoka of Buddhist and Purāṇic legends. It should be noted that the link between the edicts or inscriptions and Aśoka is a tenuous one. It has been based mainly on the name Piyadassi, which in the Pāli sources is indeed used for Aśoka. In the inscriptions, however, the name Aśoka is rare. It is found only in the

46 This is not contradictory with the finding that the texts were occasionally misunderstood. Even though these misunderstandings may have affected whole passages, they appear to have been based in details. 
Minor Rock Edicts, and in fact only in some versions of these edicts. ${ }^{47}$ It cannot be coincidental that the Minor Rock Edicts are specifically concerned with the Buddhist cause. ${ }^{48}$

In this respect the situation of the name used by the Buddhists, namely Piyadassi, is different. It is found in the common "formula" devānampiye piyadasi lājā. In the Greek version of this formula piyadasi has been left untranslated, which would show that it was taken as a personal name. Note in this connection also the substitution of piyadasi in MRE II in, for instance, Udegolam by the personal name asoko (see n. 47) and in the Nāgārjunī Hill Cave Inscriptions of Daśaratha (Sircar 1993: 77-78) by the personal name dasalatha. However, we should seriously reckon with the possibility that piyadasi was in origin not a personal name at all, but part of a descriptive title. As I see it, devānampiya piyadasi would form a meaningful combination as a title: while devānampiya ${ }^{49}$ may be taken to imply that the king $(l \bar{a} j \bar{a})$ rules by the grace of the gods, piyadasi could be construed as a reference to the king's manifestation on earth. It is not difficult to understand then why in some inscriptions it was piyadasi, which would thus refer to the king's earthly existence, which was sacrificed in favour of his personal name.

Whatever is exactly the case here, all this does not mean that the emperor of the Rock and Pillar Edicts could not be the same king whom the Buddhists remember under the name of Aśoka. In this connection it should be noted that the image of the emperor provided in the inscriptions, namely that of a law-giver, reformer, political thinker and supporter of heretical sects, including the Buddhists, corresponds with that of Aśoka as presented by the Buddhists. As monuments, the Rock and Pillar Edicts assume a cult around such a figure, evidence for which is indeed otherwise found in the Theravāda Buddhist tradition concerning Aśoka. Mutatis mutandis the inscriptions would be the earliest evidence of the Buddhist legend. The few isolated instances of the name Aśoka in the "Buddhist" Minor Rock Edicts (see above, n. 47) may well

${ }^{47}$ MRE I in Gujarā opens with the genitive phrase devānampiyasa piyadasino asokarāja $[s a]$ (Andersen 1990: 50), and Maski has here devānampiyasa asokasa (Andersen 1990: 61). In Nițțur MRE I ends with rājā asoko āhā taț $\bar{a} \bar{a}$ ti and MRE II opens with rājā asoko hevam āha (Andersen 1990: 68). The opening of the MRE II of Udegolam reads: rājā asoko devānampiyo hevam ăha (Andersen 1990: 109).

48 This is a fact which has been overlooked by Vassilkov (1999).

49 Note that in SE I and II devānampiya is used on its own. See also RE VIII A, with devānampiy $\bar{a}$ in the $\mathrm{p}^{2}$ versions and lājāne in $\mathrm{p}^{1}$. 
represent insertions made locally by Buddhists in recognition of the importance which they assigned to Aśoka.

If it is correct that in the majority of the Aśoka inscriptions old documents were used, whether the corpus also includes inscriptions based on "new" documents drawn up to be engraved immediately is another question, as is, if the answer to this question is an affirmative one, the question of whether these documents might bring us any closer to the emperor of the old documents or, for that matter, to Aśoka. The first point to be noted in this connection is that while most of the edicts of the inscriptions were based on old documents, there are some which may have been composed for the occasion. A case in point is the fourteenth Rock Edict, which seems to serve as a kind of colophon to the series as a whole (see above, p. 9). Another instance may be the Seventh Pillar Edict, which might well be a later fabrication. Other candidates are the two so-called Separate Edicts found only in the Dhauli and Jaugada versions of the Rock Edict series in the place of Rock Edicts XI, XII and XIII. ${ }^{50}$

Secondly, as I have argued, piyadasi occurring in the edicts may well be a title and as such, rather than referring specifically to the Aśoka known from Buddhist and Purānic legends, could refer to any king of the same dynasty. Furthermore, the instances of the name Aśoka, found mainly in the "Buddhist" inscriptions, may well be later additions. A special case among the so-called Buddhist inscriptions is the one on a stone slab found at Bairāt and presently kept in Calcutta (Hultzsch 1925: 172-174). The inscription is curious for its reference to individual Buddhist texts, some of which have been identified with texts or sections of texts of the present Theravāda canon (Schmithausen 1992: 113-117). However, the most curious feature of the inscription is that where it identifies the ruling king with the words piyadasi lāj $\bar{a}$ māgadhe, that is, "king Piyadasi from Magadha", it contains an absolutive (abhivāde[..]nam = abhivādetunam) that is almost certainly not regularly eastern and is otherwise attested only relatively late (see Tieken 1998). I think we should reckon with the fact that the text of Bairāt is a fabrication. ${ }^{51}$

50 In a forth-coming article, titled "The Interrogative Pronouns kāni, kam, and kimti in the Aśoka Edicts", I will try to show that the edicts mentioned just now share a linguistic innovation, which sets them apart from the other edicts.

${ }_{51}$ In this regard it should be noted that till late into the first millennium A.D. the Aśoka inscriptions remained important symbols in Buddhism, as becomes clear from finds of souvenirs sold to pilgrims consisting of miniature copies of the inscriptions (see Falk 1993). 
The case of the inscriptions from Rummindeī and Nigālī Sāgar is different again. Both mention a visit to the sites in question by the emperor personally in his fourteenth and twentieth years respectively. On the occasion of his visit to Nigāli Sāgar the emperor gave orders to expand the stupa dedicated to the Buddhist saint Konākamana and to erect an inscribed pillar. The Rummindeī inscription mentions the erection of the pillar and the building of some unidentified object. In addition to that, Rummindei, because it was the place of birth of the Buddha, was granted freedom from certain taxes (see Falk 1991). Given the practical matters dealt with in these two inscriptions - note especially the tax reduction in Rumminde $\overline{\mathbf{1}}$ - we are most likely dealing with inscriptions of the ruling monarch. However, given the possibility that the phrase devānampiye piyadasi lāja contains only titles and no personal names (see above) no definite conclusions can be drawn regarding the identity of the ruler. In addition, the fact that the texts of the respective inscriptions are almost the same need not mean that we are indeed dealing with the same king. In this connection, I would like to draw attention to two almost identical inscriptions found in Elvend (Iran), the one from Darius, the other from Xerxes (see Lecoq 1997: 127).

The inscriptions that might bring us closest to the Aśoka of Buddhist and Purānic legends are the three Nāgārjunī Hill Cave Inscriptions of Daśaratha (Sircar 1993: 77-78). They commemorate donations of caves to the Ājīvikas by dașalatha devānampiya, who in the Purānic sources is mentioned among Aśoka's successors (Pargiter 1913: 27-28). It is interesting to note that these inscriptions testify to the sudden rise in royal favour of the Ājīvika sect. Apparently, Daśaratha's ascension to the throne meant an immediate and complete reversal of the fate of the $\bar{A}$ jīvikas, since the first thing the new king did (ānamtaliyam abhisiten $\bar{a}$ ) was to donate caves to them for shelter during the rainy season. ${ }^{52}$ If the Daśaratha of the Nāgārjunī inscription is indeed the Daśaratha who succeeded Aśoka, another coincidence becomes evident: the concluding expression in the Nāgārjunī inscriptions, ācamdamasüliyam "for as long as the sun and moon (will shine)", is as far as the corpus of Aśoka inscriptions is concerned found only in the Sāñcī ver-

52 The occurrence of such abrupt switches between generations of kings in the support of religious sects must have been a regular phenomenon. Otherwise the later tradition, according to which the Buddhists were supported by Aśoka and their rivals, the Jainas, by his ancestor Candragupta (see Trautmann 1971: 27), would not have been convincing. 
sion of the Schism Edict, which is a secondary version of that edict (see Tieken 2000: 23-25), and in the later PE VII, namely in OO: se etāye athāye iyam kate putāpapotike camdamasuliyike hotu ti tathā ca anupatipajamtu ti, "Now for the following purpose has this been ordered, that it may last as long as (my) sons and great-grandsons (shall reign and) as long as the moon and the sun (shall shine), and in order that (men) may conform to it" (Hultzsch 1925: 137).

The corpus of Aśoka inscriptions includes three other inscriptions commemorating the donations of cave-cells to Ājīvikas, namely the Barābar Hill Cave Inscriptions (Sircar 1993: 75-76). Two of them have been dated to the twelfth and one to the nineteenth year of a king called Piyadassi. However, there remains the question whether this Piyadassi, who supported Ājīvikas, can have been any immediate predecessor of the Daśaratha of the Nāgārjunī inscriptions, who seem to have broken with the practice of his predecessor by starting to support Ājīvikas. Then also remains the question whether he was the same ruler who wrote the original Rock and Pillar Edicts. Note in this connection that where the Rock Edicts and Pillar Edicts speak only of śramanas in general, the $\bar{A}$ jīvikas are mentioned by name only in PE VII, which, as argued above, p. 27f., may well be a later imitation of a Pillar Edict text.

Aśoka of the inscriptions is generally believed to have reigned between 268 and 233 B.C. (Eggermont 1956: 180-189). This dating has been based on, among other things, the identification of the Hellenistic kings mentioned in RE XIII, who would have been his contemporaries. As such, the Aśoka inscriptions play an important role in the establishment of the chronology of India's early history. For instance, the time of the Buddha has been calculated by counting backwards from Aśoka (Schmithausen 1992) and early epigraphic documents are generally dated on the basis of a comparison of their scripts with those of the Aśoka inscriptions. However, the dating of Aśoka, or the Aśoka inscriptions, has been based on a circular argument. That is to say, the only Hellenistic kings considered were from the middle of the third century B.C. Thus, according to Hultzsch (1925: xxxv-xxxvi) Amtiyoka could not be Antiochus I, because that king was too early, and for similar reasons Alikasudara must have been Alexander of Corinth (252-244) rather than Alexander of Epirus. All other evidence for Aśoka's dates is of a legendary nature. A new factor to be reckoned with now is that the inscriptions might be posthumous; it is difficult to estimate with any certainty the number of generations intervening between the em- 
peror who issued the original edicts, on the one hand, and the Rock Edict and Pillar Edict inscriptions, on the other. In trying to date the inscriptions anew we should now first make a distinction between the original documents, their supposed storage in the royal archives and their recycling in the inscriptions. As I see it, this whole complex of activities will somehow have to be compressed into a period probably not much longer than three centuries. Thus, while the emperor of the original missives must have lived during or after the establishment of Greek settlements on the northwestern borders of India, the inscriptions most likely predate the inscriptions of, for instance, the Sātavāhanas from the first century B.C. onwards - for the latter inscriptions signal a new political situation not compatible with the imperial ambitions emanating from the texts and the distribution of the Aśoka inscriptions.

\section{Bibliography and Abbreviations}

Allchin - Norman 1985

Alsdorf 1962

Alsdorf 1974

Andersen 1986

Andersen 1990

Arthaśāstra

Benveniste 1966

Bloch 1950

Briant 1996

Caillat 1966
F.R. Allchin - K.R. Norman, A Guide to the Aśokan Inscriptions. South Asian Studies I (1985) 43-50.

L. Alsdorf, Aśokas Separatedikte von Dhauli und Jaugada. [AAWL 1962/2]. Wiesbaden: Franz Steiner, 1962 (= Alsdorf 1974: 464-498).

Id., Kleine Schriften, ed. A. Wezler. [Glasenapp-Stiftung, Bd. 10]. Wiesbaden: Franz Steiner, 1974.

P.K. Andersen, Die $t a$-Partizipialkonstruktion bei Aśoka: Passiv oder Ergativ?. Zeitschrift für vergleichende Sprachforschung 99 (1986) 75-94.

Id., Studies in the Minor Rock Edicts of Aśoka. I. Critical Edition. Freiburg: Hedwig Falk, 1990.

The Kautilīya Arthaśāstra, ed. \& tr. R.P. Kangle. Part I: A Critical Edition with a Glossary. [University of Bombay Studies Sanskrit, Prakrit and Pali 1]. Bombay ${ }^{2} 1969$.

E. Benveniste, Une inscription indo-araméenne d'Asoka provenant de Kandahar (Afghanistan). II. Identification du texte. Les parties indiennes. Journal Asiatique 254 (1966) 446-453.

J. Bloch, Les inscriptions d'Aśoka. [Collection Émile Senart 8]. Paris: Les Belles Lettres, 1950.

P. Briant, Histoire de l'empire perse de Cyrus à Alexandre. Paris: Fayard, 1966.

C. Caillat, La séquence SHYTY dans les inscriptions indoaraméennes d'Asoka. Journal Asiatique 254 (1966) 467 470 . 
CII III

Eggermont 1956

Falk 1991

Falk 1993

Goodall 2001

Henning 1950

Hultzsch 1925

Lecoq 1997

Norman 1987

Pargiter 1913

Ramesh 1990

Sarkar 1971

Schmithausen 1992

Schneider 1973
Corpus Inscriptionum Indicarum. Volume III. Inscriptions of the Early Gupta Kings, ed. D.R. Bhandarkar - B. Chhabra - G.S. Gai. New Delhi: Archaeological Survey of India, 1981.

P.H.L. Eggermont, The Chronology of the Reign of Asoka Moriya. A comparison of the data of the Asoka inscriptions and the data of the tradition. Leiden: E.J. Brill, 1956

H. Falk, Zur Geschichte von Lumbinī. AcOr 52 (1991) 70-90. Id., Spurious Aśokan Records. ABORI 72-73 (1993) 263-273.

D. Goodall, bhūte 'ăha' iti pramadāt: Firm Evidence for the Direction of Change Where Certain Verses of the $R a$ ghuvamśa are Variously Transmitted. ZDMG 151 (2001) 103-131.

W.B. Henning, The Aramaic Inscriptions of Asoka found in Lampāka. BSOAS 13 (1949-1950) 80-89.

E. Hultzsch, Inscriptions of Asoka. [Corpus Inscriptionum Indicarum I]. Oxford 1925 (repr.: Varanasi: Indological Book House, 1969).

P. Lecoq, Les inscriptions de la Perse achéménide. Paris: Gallimard, 1997.

K.R. Norman., The Inscribing of Aśoka's Pillar Edicts. In: India and the Ancient World: History, Trade and Culture before A.D. 650. [Orientalia Lovaniensia Analecta 25]. Leuven 1987, p. 131-139 (= Collected Papers III. Oxford 1992, p. 173-182).

F.E. Pargiter, The Purāna Text of the Dynasties of the Kali Age with Introduction and Notes. London: Humphrey Milford, 1913.

K.V. Ramesh, The Aśokan Inscriptions at Sannathi. The Indian Historical Review 14,1-2 (1987-1988[90]) 36-42.

H.B. Sarkar, Corpus of the Inscriptions of Java / Corpus Inscriptionum Javanicarum (upto 928 A.D.). Calcutta: Mukhopadhyay, 1971.

L. Schmithausen, An Attempt to Estimate the Distance in Time between Aśoka and the Buddha in Terms of Doctrinal History. In: The Dating of the Historical Buddha / Die Datierung des historischen Buddha, ed. H. Bechert. Part 2. [Symposium zur Buddhismusforschung IV,2]. Göttingen 1992, p. 110-147.

U. Schneider, Zum Stammbaum der großen Felseninschriften Aśokas. In: Indologen-Tagung 1971, ed. H. Härtel and V. Moeller. Wiesbaden 1973, p. 224-237. 
Schneider 1978

Shaked 1969

Sircar 1993

Stein 1935

Tieken 1998

Tieken 2000

Trautmann 1971

Vassilkov 1999

Wright 2000

Zimmermann 1987
Id., Die grossen Felsen-Edikte Aśokas. Kritische Ausgabe, Uebersetzung und Analyse. [Freiburger Beiträge zur Indologie 11]. Wiesbaden: Otto Harrassowitz, 1978.

Sh. Shaked, Notes on the New Aśoka Inscription from Kandahar. Journal of the Royal Asiatic Society of Great Britain and Ireland 1969, p. 118-122.

D.Ch. Sircar, Select Inscriptions Bearing on Indian History and Civilization. Vol I. New Delhi: V.K. Publishing House (repr.), 1993.

O. Stein, Arthaśāstra and Śilpaśāstra. ArO 7 (1935) 473-487 (= Kleine Schriften, ed. F. Wilhelm. [Glasenapp-Stiftung, Bd. 25]. Stuttgart 1985, p. 366-380).

H. Tieken, The Distribution of the Absolutive in - $\bar{u}$ na $a(m)$ in Uttarajjhāyā. Asst 52 (1998) 261-286.

Id., Aśoka and the Buddhist Samgha: A Study of Aśoka's Schism Edict and Minor Rock Edict I. BSOAS (2000) 130 .

Th.R. Trautmann, Kautilya and the Arthaśāstra. A statistical investigation of the authorship and evolution of the text. Leiden: E.J. Brill, 1971.

Y.V. Vasilkov, On the Meaning of the Names Aśoka and Piyadasi. IndT 23-24 ([= Professor Gregory M. BongardLevin Felicitation Volume] 1997-1998[99]) 441-457.

C. Wright, Aśoka's 256-Night Campaign. JRAS 3rd series, 10 (2000) 319-339.

F. Zimmermann, The Jungle and the Aroma of Meats. An Ecological Theme in Hindu Medicine. Berkeley: University of California Press, 1987. 